\title{
Effects of supplemental calcium gluconate embedded in a hydrogenated fat matrix on lactation, digestive, and metabolic variables in dairy cattle
}

\author{
D. J. Seymour, (1) M. V. Sanz-Fernandez, ${ }^{*}$ (1) J. B. Daniel, (1) J. Martín-Tereso, (i) and J. Doelman (1) \\ Trouw Nutrition R\&D, PO Box 299, 3800 AG, Amersfoort, the Netherlands
}

\begin{abstract}
There is growing evidence suggesting that by improving gut integrity and function, less energy is partitioned toward immune responses related to xenobiotic infiltration, sparing energy for productive purposes. Gluconic acid and its salts have previously shown prebiotic effects in the lower gut of nonruminant animals, where they serve as a precursor for butyrate, although evidence in ruminants is limited. Butyrate and its fermentative precursors have demonstrated multiple beneficial effects to gastrointestinal ecology, morphology, and function, such as the stimulation of epithelial cell proliferation and improvement of gut barrier function and ecology. The objective of this study was to evaluate changes in milk production, milk fatty acid composition, and fecal and blood parameters in lactating dairy cattle fed a hydrogenated fat-embedded calcium gluconate (HFCG) supplement designed to target the hindgut for calcium gluconate delivery. In addition, the effects of a compound feed processing method (i.e., incorporated into a mash or an extruded pellet) were tested to evaluate the effect of extrusion on product efficacy. Forty-five lactating Holstein cows at approximately $165 \mathrm{~d}$ in milk were used in a $3 \times 3$ Latin square consisting of three 28 -d periods, during which animals were offered a basal ration mixed with 3 different compound feeds: a negative control in mash form containing no HFCG, or the HFCG supplement fed at a target rate of $16 \mathrm{~g} / \mathrm{d}$, delivered in either a mash or pelleted form. Supplementation of HFCG tended to increase yields of milk fat and fat- and energy-corrected milk. Total yields and concentrations of milk fatty acids $\geq 18$ carbons in length tended to increase in response to HFCG. Plasma nonesterified fatty acids and milk urea increased in HFCG treatments. No differences were observed in fecal $\mathrm{pH}$ or fecal concentrations of volatile fatty acids, with the exception of iso-
\end{abstract}

Received December 9, 2020.

Accepted February 26, 2021.

*Corresponding author: Victoria.sanz-fernandez@trouwnutrition .com butyrate, which decreased in HFCG-fed cows. Changes in milk fatty acid profile suggest that increased milk fat yield was driven by increased incorporation of preformed fatty acids, supported by increased circulating nonesterified fatty acid. Future research investigating the mode of action of HFCG at the level of the hindgut epithelium is warranted, as measured fecal parameters showed no response to treatment.

Key words: hindgut, prebiotic, milk fat

\section{INTRODUCTION}

The gastrointestinal tract is highly sensitive to a plethora of factors intrinsic to the lifecycle of dairy cows. As recently reviewed by Sanz-Fernandez et al. (2020), the hindgut is susceptible to acidosis, much like the rumen; however, due to a variety of physiological and structural differences, it may be less capable of tolerating an acidotic challenge than the rumen, resulting in increased permeability to xenobiotic compounds and the repartitioning of energy to support an immune response (Fox et al., 2005; Kvidera et al., 2017). In human and nonruminant models, eubiotic supplementation is an extensive practice aimed at promoting microbiome stability in the large intestine. Gluconic acid is a mild organic acid 6 carbons in length with an acid dissociation constant $\left(\mathrm{p} K_{\mathrm{a}}\right)$ of 3.7 , produced by the dehydrogenation of glucose by various fermentative microorganisms (Ramachandran et al., 2006), which acts as a prebiotic in nonruminant species by passing through the stomach and small intestine with minimal digestion and absorption, allowing it to be fermented by microbes in the lower gut, and resulting in improved production performance (Biagi et al., 2006; Poeikhampha and Bunchasak, 2011; Michiels et al., 2020). This association between prebiotic supply and animal performance is thought to be mediated by changes in microbial VFA production (Tsukahara et al., 2002, 2006; Biagi et al., 2006).

The beneficial effects of VFA on intestinal health are broadly accepted. Increased VFA supply (Velazquez et al., 1997; Hamer et al., 2008), and in particular increased butyrate (Sakata and Tamate, 1978; Gálfi et al., 1991; 
Mentschel et al., 2001), induces epithelial cell proliferation in the gut in ruminant and nonruminant models. Butyrate supports homeostasis in the gastrointestinal tissues by modulating the balance between proliferation, apoptosis, and differentiation, while stimulating increases in local blood flow (Kristensen and Harmon, 2004; Hamer et al., 2008). When butyrate levels are clinically low, supplementation with butyryl esters has proven to be an effective therapy, particularly in individuals with chronic inflammation and loss of function in the absorptive surfaces of the gut (Wachtershauser and Stein, 2000; Miyoshi et al., 2011; Leonel et al., 2013). The effects of ruminal butyrate supplementation are well documented (Huhtanen et al., 1993; Miettinen and Huhtanen, 1996; Herrick et al., 2018), as are the effects of butyrate in nonruminant species (Biagi et al., 2006; Poeikhampha and Bunchasak, 2011; Michiels et al., 2020). However, there is a lack of information on the effects of butyrate in the lower gut of ruminants, more specifically the lactating dairy cow, and the exact mode of action of butyrate in the hindgut is also not well defined (as reviewed by den Besten et al., 2013; Liu et al., 2018).

Given the performance responses reported in nonruminant applications, there are potential benefits to providing hydrogenated fat-embedded gluconic acid in the mature ruminant. Postruminal infusion of calcium gluconate, a gluconic acid salt, has resulted in changes in fecal VFA profile and improved milk fat concentration in lactating dairy cows (Doelman et al., 2019b; McKnight et al., 2019). In a recent pilot study conducted by our group, a hydrogenated fat-embedded calcium gluconate (HFCG) compound fed to early-lactation dairy cows increased milk fat concentration and yield (Doelman et al., 2019a), in contrast to the null response observed when incorporating calcium gluconate directly into the diet without embedding it in fat (McKnight et al., 2019). This suggests that the hydrogenated fat matrix offers some degree of protection to the calcium gluconate from degradation in the rumen (Papas and Wu, 1997; Wu et al., 2012), and that following digestion of the fat matrix in the small intestine, the active ingredient is liberated and available for fermentation in the hindgut. A recent in sacco study conducted by our group (unpublished) showed 75 to $80 \%$ retention of calcium gluconate when HFCG was incubated for $6 \mathrm{~h}$. This suggests that although a portion of the calcium gluconate in the product may be able to solubilize in the rumen environment or be available for catabolism by rumen microbiota, the majority is able to remain intact.

The objective of the current study was to test the efficacy of supplementing calcium gluconate embedded in a hydrogenated fat matrix on milk production, milk fatty acid profile, fecal VFA composition, and circulating metabolites in lactating dairy cows. Additionally, 2 methods of delivery of the calcium gluconate supplement (incorporated into either a mash or pellet compound feed) were tested to assess any effects of feed processing, specifically any changes due to pelleting at high temperatures. We hypothesized that supplementation with the HFCG product would result in increased milk fat concentration and yield relative to the control group, with minimal differences between delivery methods.

\section{MATERIALS AND METHODS}

This study was conducted at the Trouw Nutrition Dairy Research Facility (Boxmeer, the Netherlands) between April and June 2016. The study complied with the Dutch Act on Animal Experiments, which complies to European Directive 2010/63/EU, and was approved by the competent authority, the Centrale Commissie Dierproeven.

\section{Animal Feeding and Management}

For the duration of the study, animals were group housed in a freestall barn. Both feed and water were provided ad libitum. Feed was delivered as a TMR daily at approximately $1000 \mathrm{~h}$, and individual daily feed intakes were monitored using electronic feed bunks (RIC system; Hokofarm Group B.V.). The basal ration (Table 1) consisted of corn silage, grass silage, grass hay, and a compound feed and was formulated to provide an estimated $7.01 \mathrm{MJ}$ of $\mathrm{NE}_{\mathrm{L}} / \mathrm{kg}$ of $\mathrm{DM}$ and $15.4 \%$ CP. Samples of the basal ration were collected 3 times per week $(\sim 500 \mathrm{~g} / \mathrm{sample})$ and stored at $-20^{\circ} \mathrm{C}$ until analysis. At that time, samples were thawed, pooled by week, and analyzed in triplicate for DM content as described by Seymour et al. (2019). Proximate analyses were conducted using wet chemistry by MasterLab (Boxmeer, the Netherlands).

\section{Experimental Design}

Based on milk fat responses from previous studies (Doelman et al., 2019a,b; McKnight et al., 2019), a sample size calculation was performed to determine the number of animals required to detect a $0.17 \%$ difference in milk fat concentration, given a herd average milk fat concentration of $4.20 \%$, standard deviation (SD) of $0.30 \%$, and type I error rate of $5 \%$. Based on these calculations, 45 lactating Holstein-Friesian dairy cattle $(165 \pm 53$ DIM at the beginning of the study, mean \pm SD) were enrolled in a study utilizing a $3 \times 3$ replicated Latin square design consisting of 3 consecutive $28-\mathrm{d}$ 
Table 1. Formulation and chemical composition of basal ration ${ }^{1}$

\begin{tabular}{lc}
\hline Item & Content \\
\hline Ingredient & \\
Corn silage & 41.4 \\
Compound feed ${ }^{2}$ & 32.8 \\
Grass silage & 20.4 \\
Grass hay & 5.4 \\
Composition & \\
DM (\%) & 49.2 \\
NE $(\mathrm{MJ} / \mathrm{kg}$ of DM) & 7.01 \\
CP & 15.4 \\
Starch & 25.0 \\
NDF & 32.3 \\
ADF & 17.8 \\
ADL & 1.86 \\
Crude fat & 3.28 \\
Ash & 8.58 \\
Ca & 0.58 \\
P Na & 0.37 \\
K & 0.17 \\
Vitamin A (IU/kg of DM) & 1.60 \\
Vitamin D (IU/kg of DM) & 2,996 \\
Vitamin E (IU/kg of DM) & 749 \\
\hline
\end{tabular}

${ }^{1}$ Values are presented as a percentage of DM unless stated otherwise. ${ }^{2}$ Contained (as-fed \%) corn (38.19), 48\% CP soybean meal (16.84), rumen-protected rapeseed meal (10.00), solvent-extracted rapeseed meal (10.00), wheat (7.74), soy hulls (5.64), cane molasses (5.00), rumenprotected soybean meal (1.71), limestone (1.59), urea (1.50), vitamin/ mineral premix (1.40), and vitamin E (0.02).

${ }^{3}$ Addition of hydrogenated fat-embedded calcium gluconate increased crude fat to approximately $3.31 \%$ DM.

periods. Each period consisted of $24 \mathrm{~d}$ of adaptation followed by $4 \mathrm{~d}$ of data and sample collection. Multiparous cows $(\mathrm{n}=31)$ were blocked by parity and average daily yields of milk, fat, and protein during the previous lactation. Primiparous heifers $(\mathrm{n}=14)$ with no previous production records were blocked by expected production based on genetic evaluation. Treatment sequences were randomly assigned to each animal within a block by the study investigators. Treatments consisted of a negative control mash (e.g., no HFCG supplementation) and 2 delivery forms of the HFCG supplement (Trouw Nutrition), one being a mash application, and the other a pellet extruded at $80 \pm 3{ }^{\circ} \mathrm{C}$. The HFCG supplement (50\% hydrogenated palm fat, $40 \%$ calcium gluconate, $10 \%$ calcium carbonate) was incorporated into the compound feed at an inclusion rate of $1.93 \mathrm{~kg} / \mathrm{t}$ to achieve a targeted inclusion of $0.07 \%$ DM, corresponding to approximately $16 \mathrm{~g}$ of supplement per day, providing $6.40 \mathrm{~g}$ of calcium gluconate at the targeted intake of $22.31 \mathrm{~kg}$ of DM per day. Because treatments were administered in different physical forms, no blinding was used. All animals started the experiment on the same day and were acclimated to the negative control ration for $2 \mathrm{wk}$ before the start of the first period. After exiting the milking parlor, animals were weighed daily, using an inline scale, and the average BW from d 25 to 28 of each period was evaluated.

\section{Blood and Fecal Analyses}

Blood samples were collected at 0800 and $1300 \mathrm{~h}$ on d 28 from the coccygeal vessels into $10-\mathrm{mL}$ sodium heparin and potassium EDTA blood collection tubes (Becton, Dickinson and Co.). Samples were immediately stored on ice until centrifugation at $4^{\circ} \mathrm{C}$ at 1,500 $\times g$ for $15 \mathrm{~min}$, after which plasma was aliquoted into polypropylene vials. Plasma samples collected at 0800 $\mathrm{h}$ were stored at $4^{\circ} \mathrm{C}$ until the collection of samples at $1300 \mathrm{~h}$, after which plasma aliquots from both time points were pooled by preservative type and stored at $-20^{\circ} \mathrm{C}$ until analysis by MasterLab (Boxmeer, the Netherlands). Spectrophotometric assays were used to determine the plasma concentrations of acetic acid (K-ACETRM kit, Megazyme), glucose (Glucose GO assay kit, Sigma-Aldrich; Raabo and Terkildsen, 1960), nonesterified fatty acids (NEFA; NEFA-HR(2) kit, Fujifilm Wako Chemicals Europe GmbH; Johnson and Peters, 1993), BHB (Cant et al., 1993), triacylglycerol (Weekes et al., 2006), insulin (Rat Insulin ELISA Kit, Crystal Chem Inc.; Nichols et al., 2016), cholesterol (Cholesterol Quantitation Kit, Sigma-Aldrich), and growth hormone (Weber et al., 2007).

At $1300 \mathrm{~h}$ on d 28 of each period, approximately 150 to $200 \mathrm{~g}$ of fresh feces was collected directly from the rectum for the determination of DM content. A second sample of approximately $5 \mathrm{~g}$ was collected for the determination of VFA composition. Both samples were stored on ice in sealed plastic bags until analysis. Dry matter content was determined by drying in an oven at $60^{\circ} \mathrm{C}$ for $48 \mathrm{~h}$. For determination of VFA content, $5 \mathrm{~g}$ of fresh feces was dissolved in $10 \mathrm{~mL}$ of water and mixed thoroughly, and the $\mathrm{pH}$ was measured using a glass electrode. An aliquot of approximately $6 \mathrm{~mL}$ was centrifuged at $2,700 \times g$ at $10^{\circ} \mathrm{C}$ for $15 \mathrm{~min}$, and a 1-mL aliquot of the supernatant was subsequently mixed with $0.5 \mathrm{~mL}$ of $0.02 \mathrm{M}$ sulfuric acid stored at $-20^{\circ} \mathrm{C}$ until VFA analysis by HPLC.

\section{Milk Samples}

Animals were milked twice daily at 0500 and $1700 \mathrm{~h}$. Milk yields were recorded automatically at each milking. Milk was sampled on Tuesday and Thursday mornings and Monday and Wednesday evenings between d 25 and 28 of each experimental period. Samples were collected in tubes containing sodium azide and bronopol as preservatives and stored at $4^{\circ} \mathrm{C}$. Samples were pooled within animal by weighing each individual 
sample proportionally to yield per milking. Samples were analyzed for fat, CP, lactose, and urea concentration (Qlip, Deventer, the Netherlands) using a Foss Milkscan FT6000 (Foss; ISO, 2013). Yields of ECM were calculated as $[0.01 \times$ milk yield $(\mathrm{kg} / \mathrm{d})+12.2 \times$ fat yield $(\mathrm{kg} / \mathrm{d})+7.7 \times$ protein yield $(\mathrm{kg} / \mathrm{d})+5.3 \times$ lactose yield (kg/d); Sjaunja et al., 1990], whereas $4 \%$ FCM yields were calculated as $[0.4 \times$ milk yield $(\mathrm{kg} / \mathrm{d})$ $+15 \times$ fat yield $(\mathrm{kg} / \mathrm{d})$; Gaines, 1928].

Additional milk samples were collected for the determination of milk fatty acid content where samples were pooled within animal by weighing each individual sample proportionally to yield per milking. After blocking and treatment allocation, cows within a treatment were randomly assigned to 1 of 3 groups consisting of 5 cows per group. There were 9 groups across the total of 45 cows used in this experiment, and cows remained in their groups for the duration of the experiment. A 1-mL sample of milk from each animal was pooled within treatment group, resulting in a 5 -mL sample per treatment group per period. Pooled samples were stored at $-20^{\circ} \mathrm{C}$ until analysis by GC-MS at Qlip. Milk fatty acid content of pooled samples was considered representative of the average fatty acid content of milk from animals within treatment groups within periods. Milk fatty acid yields of individual animals were estimated by multiplying the individual milk fat yield of an animal within a period by the milk fatty acid content of the corresponding pooled sample.

\section{Statistical Analyses}

All statistical analyses were conducted using the GLIMMIX procedure of SAS v9.4 (SAS Institute Inc., Cary, NC). For data pertaining to animal performance, blood metabolites and fecal VFA content, the statistical model used was

$$
\begin{aligned}
& y_{i j k l m}=\mu+\text { trt }_{i}+\text { block }_{j}+\text { period }_{k}\left(\text { block }_{j}\right) \\
& +\operatorname{cow}_{l}\left(\text { block }_{j}\right)+\text { parity }_{m}+\varepsilon_{i j k l m},
\end{aligned}
$$

where $y$ is the response variable, $\mu$ is the overall mean, and $\varepsilon_{i j k l m}$ is the residual error. The effects of treatment $\left(\right.$ trt $\left._{i} ; i=1-3\right)$, period within block ( period $\left._{k} ; k=1-3\right)$, and parity group ( parity $_{m} ; m=1,2$, primiparous or multiparous) were considered fixed, whereas the effects of block (block; $j=1-15)$ and animal within block ( cow $_{l}$; $l=1-3$ ) were considered random. Because samples for the determination of milk fatty acid content were pooled by treatment group within period, these data were analyzed with a model considering treatment and period as fixed effects, with sample pooling group as a random effect. In all analyses, the Kenward-Roger correction was used to adjust the denominator degrees of freedom, and orthogonal contrasts were used to perform specific hypothesis tests comparing the pooled effect of HFCG supplementation relative to control, and the effect of processing method. Significance was declared where $P$ $<0.05$, and tendencies where $0.05 \leq P<0.15$.

\section{RESULTS}

\section{Fecal VFA Content and $\mathrm{pH}$}

Fecal VFA content and $\mathrm{pH}$ are presented in Table 2. No significant differences were observed between treatment groups for $\mathrm{pH}$ or concentrations of acetate, propionate, or butyrate. Isobutyrate concentrations decreased $(\sim 15 \% ; P \leq 0.001)$ in response to $\mathrm{HFCG}$

Table 2. Fecal pH, DM, and VFA content in response to supplementation with fat-embedded calcium gluconate

\begin{tabular}{|c|c|c|c|c|c|c|}
\hline \multirow[b]{2}{*}{ Item } & \multirow[b]{2}{*}{ Control } & \multicolumn{2}{|c|}{ Supplement } & \multirow[b]{2}{*}{$\mathrm{SED}^{1}$} & \multicolumn{2}{|c|}{$P$-value ${ }^{2}$} \\
\hline & & Mash & Pellet & & HFCG & Process \\
\hline $\mathrm{pH}$ & 6.55 & 6.54 & 6.56 & 0.031 & 0.990 & 0.421 \\
\hline DM (\%) & 13.0 & 13.0 & 13.0 & 0.27 & 0.929 & 0.992 \\
\hline \multicolumn{7}{|l|}{$\mathrm{VFA}(\mu \mathrm{mol} / \mathrm{g})$} \\
\hline Acetate & 522 & 522 & 505 & 19.3 & 0.625 & 0.378 \\
\hline Propionate & 137 & 134 & 131 & 5.1 & 0.287 & 0.608 \\
\hline Butyrate & 85.7 & 85.9 & 88.1 & 5.35 & 0.778 & 0.689 \\
\hline Isobutyrate & 17.1 & 15.6 & 13.6 & 0.68 & $<0.001$ & 0.004 \\
\hline \multicolumn{7}{|c|}{ VFA $(\mu \mathrm{mol} / \mathrm{g}$ of $\mathrm{DM})$} \\
\hline Acetate & 4,090 & 4,070 & 3,950 & 172 & 0.598 & 0.473 \\
\hline Propionate & 1,060 & 1,030 & 1,020 & 43.1 & 0.270 & 0.842 \\
\hline Butyrate & 654 & 657 & 687 & 42.1 & 0.714 & 0.613 \\
\hline Isobutyrate & 133 & 120 & 106 & 6.0 & 0.001 & 0.017 \\
\hline
\end{tabular}
(HFCG) in either a mash or pelleted form $(\mathrm{n}=45)$

${ }^{1}$ Standard error of the difference.

${ }^{2} \mathrm{HFCG}=$ pooled calcium gluconate effect; Process = mash versus pellet effect. 
Table 3. Plasma metabolite concentrations in response to supplementation with fat-embedded calcium gluconate (HFCG) in a mash or pelleted form $(\mathrm{n}=45)^{1}$

\begin{tabular}{|c|c|c|c|c|c|c|}
\hline \multirow[b]{2}{*}{ Item } & \multirow[b]{2}{*}{ Control } & \multicolumn{2}{|c|}{ Supplement } & \multirow[b]{2}{*}{$\mathrm{SED}^{2}$} & \multicolumn{2}{|c|}{$P$-value ${ }^{3}$} \\
\hline & & Mash & Pellet & & HFCG & Process \\
\hline Glucose & 3.69 & 3.67 & 3.76 & 0.043 & 0.551 & 0.033 \\
\hline Nonesterified fatty acids & 0.065 & 0.085 & 0.097 & 0.0098 & 0.003 & 0.225 \\
\hline BHB & 0.766 & 0.757 & 0.708 & 0.0239 & 0.116 & 0.046 \\
\hline Triacylglycerol & 0.087 & 0.086 & 0.086 & 0.0024 & 0.559 & 0.927 \\
\hline Cholesterol & 4.70 & 4.80 & 4.77 & 0.071 & 0.180 & 0.731 \\
\hline Insulin (mIU/L) & 16.1 & 16.2 & 15.6 & 0.73 & 0.730 & 0.477 \\
\hline Somatotropin $(\mathrm{ng} / \mathrm{mL})$ & 2.33 & 2.18 & 2.35 & 0.111 & 0.509 & 0.126 \\
\hline
\end{tabular}

supplementation and were lower in the pelleted form relative to the mash (Table 2 ).

\section{Plasma Metabolites}

Plasma metabolite concentrations are presented in Table 3. Concentrations of NEFA increased $(40.0 \% ; P$ $=0.003)$, whereas BHB tended to decrease $(4.4 \% ; P=$ 0.116) in response to HFCG supplementation. In addition, BHB was $6.5 \%$ higher $(P=0.046)$ in response to the mash relative to the pellet. Concentrations of glucose were elevated $(P=0.033)$ in response to the pellet relative to the mash, whereas concentrations of somatotropin tended to be elevated $(P=0.126$; Table $3)$.

\section{Production Responses}

Overall production responses are presented in Table 4. Milk fat yield tended to increase by approximately $35 \mathrm{~g} / \mathrm{d}(2.4 \% ; P=0.062)$ in response to HFCG supplementation, resulting in subsequent increases in yields of FCM $(2.1 \% ; P=0.056)$ and ECM $(1.8 \% ; P=0.086)$. Supplementation of HFCG increased milk urea $(7.4 \%$; $P=0.001)$ and tended to decrease milk protein content $(0.02 \% ; P=0.112$; Table 4$)$. The pelleted form of the HFCG supplement increased $(P=0.020)$ lactose content by 0.03 percentage units relative to the mash. Milk fat content did not differ between treatments (Table 4). No effect of HFCG supplementation was observed on BW (Table 4), whereas animals receiving the mash tended to be $4 \mathrm{~kg}$ heavier $(P=0.146)$ than animals receiving the pelleted form.

\section{Milk Fatty Acid Profile}

Concentrations of milk fatty acids grouped by carbon number are presented in Table 5, with differences mainly detected at the tendency threshold. Concentra- tions of individual fatty acid isomers are presented in Supplemental Table S1 (http://dx.doi.org/10.17632/ kptvz5k65d.1). Addition of HFCG stimulated a decrease $(P \leq 0.110)$ in the concentration of fatty acids ranging from 8 to 14 carbons in length, whereas concentrations of butyrate (C4:0; Figure 1), total C18 and n-3 fatty acids tended to increase $(P \leq 0.147)$. Concentrations of C16 and SFA decreased $(P \leq 0.042)$, whereas concentrations of $\mathrm{C} 22: 5$ cis-7,10,13,16,19, total UFA, n-6, MUFA, and PUFA tended to increase $(P \leq$ $0.078)$ in the pelleted treatment relative to the mash. Responses in fatty acid content grouped by source [e.g., de novo, mixed (C16), and preformed] are presented in Figure 1, and highlight a trend for increased preformed fatty acid content $(2.08 \% ; P=0.073)$ in response to the pooled effect of HFCG supplementation.

Average yield of milk fatty acids grouped by carbon number are presented in Table 6, with average yields of individual fatty acid isomers presented in Supplemental Table S2 (http://dx.doi.org/10.17632/kptvz5k65d .1). Yields of butyrate, total C17 and C18, C22:5 cis7,10,13,16,19, CLA, total UFA, n-3 and n-6, MUFA, and PUFA increased $(P \leq 0.142)$ in response to HFCG supplementation. The yield of total C16 tended to be lower $(3.2 \% ; P=0.103)$ in the pelleted treatment relative to the mash. When comparing the fatty acid groups, the yield of preformed fatty acids tended to be increased by $30.9 \mathrm{~g} / \mathrm{d}(3.9 \% ; P=0.099)$ in response to HFCG supplementation (Figure 1).

\section{DISCUSSION}

Supplementing HFCG tended to increase milk fat yield, and subsequently FCM and ECM yields. This is in agreement with our previous findings, where infusing unprotected calcium gluconate postruminally resulted in increased concentration and average yield of milk fat, as well as increased ECM yield (Doelman et al., 2019b). In contrast, incorporating unprotected calcium 
Table 4. Dry matter intake, milk production and composition, and BW in response to supplementation with fat-embedded calcium gluconate (HFCG) in a mash or pelleted form $(\mathrm{n}=45)^{1}$

\begin{tabular}{|c|c|c|c|c|c|c|}
\hline \multirow[b]{2}{*}{ Item } & \multirow[b]{2}{*}{ Control } & \multicolumn{2}{|c|}{ Supplement } & \multirow[b]{2}{*}{$\mathrm{SED}^{2}$} & \multicolumn{2}{|c|}{$P$-value ${ }^{3}$} \\
\hline & & Mash & Pellet & & HFCG & Process \\
\hline DMI & 23.8 & 23.9 & 23.6 & 0.22 & 0.957 & 0.174 \\
\hline Milk yield & 31.1 & 31.5 & 31.6 & 0.36 & 0.155 & 0.775 \\
\hline FCM vield ${ }^{4}$ & 32.0 & 32.6 & 32.6 & 0.40 & 0.056 & 0.903 \\
\hline ECM yield ${ }^{5}$ & 32.4 & 32.9 & 33.0 & 0.40 & 0.086 & 0.915 \\
\hline Gross feed efficiency $(\mathrm{kg} / \mathrm{kg})^{6}$ & 1.38 & 1.39 & 1.41 & 0.020 & 0.218 & 0.207 \\
\hline Fat yield & 1.31 & 1.34 & 1.34 & 0.020 & 0.061 & 0.766 \\
\hline Protein yield & 1.12 & 1.12 & 1.13 & 0.015 & 0.495 & 0.744 \\
\hline Lactose yield & 1.43 & 1.44 & 1.46 & 0.018 & 0.117 & 0.440 \\
\hline Fat content (\%) & 4.25 & 4.31 & 4.27 & 0.051 & 0.348 & 0.465 \\
\hline Protein content (\%) & 3.62 & 3.59 & 3.60 & 0.018 & 0.112 & 0.636 \\
\hline Lactose content (\%) & 4.59 & 4.59 & 4.62 & 0.012 & 0.133 & 0.020 \\
\hline Milk urea (mg/dL) & 27.3 & 29.4 & 29.2 & 0.69 & 0.001 & 0.837 \\
\hline BW (kg) & 571 & 574 & 570 & 2.7 & 0.683 & 0.146 \\
\hline \multicolumn{7}{|c|}{$\begin{array}{l}{ }^{1} \text { Means are expressed in } \mathrm{kg} / \mathrm{d} \text { unless stated otherwise. } \\
{ }^{2} \text { Standard error of the difference. } \\
{ }^{3} \mathrm{HFCG}=\text { pooled calcium gluconate effect; Process }=\text { mash versus pellet. } \\
{ }^{4} 4 \% \mathrm{FCM} \text { yield: } 0.4 \times \text { milk yield }(\mathrm{kg} / \mathrm{d})+15 \times \text { fat yield }(\mathrm{kg} / \mathrm{d}) . \\
\text { yield }(\mathrm{kg} / \mathrm{d}) .\end{array}$} \\
\hline
\end{tabular}

gluconate directly into the diet did not improve performance (McKnight et al., 2019). As gluconic acids salts have previously been shown to have low absorption in the small intestine (Asano et al., 1994), the present results suggest that digestion of the fat matrix in the small intestine liberated calcium gluconate, and that the observed responses in production are derived from the postruminal fermentation of calcium gluconate in the hindgut.

In addition to the overall change in milk fat content, the fatty acid profile was altered with HFCG supplementation. Fatty acids up to 14 carbons in length

Table 5. Milk fatty acid content in response to supplementation with fat-embedded calcium gluconate (HFCG) in a mash or pelleted form $(\mathrm{n}=9)$

\begin{tabular}{|c|c|c|c|c|c|c|}
\hline \multirow{2}{*}{$\begin{array}{l}\text { Fatty acid } \\
\text { content }(\%)\end{array}$} & \multirow[b]{2}{*}{ Control } & \multicolumn{2}{|c|}{ Supplement } & \multirow[b]{2}{*}{$\mathrm{SED}^{1}$} & \multicolumn{2}{|c|}{$P$-value ${ }^{2}$} \\
\hline & & Mash & Pellet & & HFCG & Process \\
\hline $\mathrm{C} 4$ & 3.47 & 3.58 & 3.54 & 0.066 & 0.147 & 0.554 \\
\hline C6 & 2.40 & 2.40 & 2.38 & 0.022 & 0.651 & 0.409 \\
\hline $\mathrm{C} 8$ & 1.42 & 1.39 & 1.38 & 0.020 & 0.110 & 0.697 \\
\hline C10 & 3.83 & 3.9 & 3.65 & 0.090 & 0.064 & 0.661 \\
\hline C11 & 0.075 & 0.067 & 0.067 & 0.0056 & 0.105 & 0.969 \\
\hline $\mathrm{C} 12$ & 4.29 & 4.10 & 4.09 & 0.097 & 0.036 & 0.876 \\
\hline C13 & 0.118 & 0.108 & 0.109 & 0.0071 & 0.151 & 0.817 \\
\hline C14 & 13.6 & 13.4 & 13.4 & 0.13 & 0.035 & 0.855 \\
\hline C15 & 1.76 & 1.72 & 1.72 & 0.024 & 0.096 & 0.769 \\
\hline C16 & 34.6 & 34.7 & 34.1 & 0.24 & 0.327 & 0.042 \\
\hline C17 & 1.31 & 1.33 & 1.35 & 0.020 & 0.213 & 0.312 \\
\hline C18 & 31.5 & 31.9 & 32.2 & 0.39 & 0.113 & 0.370 \\
\hline $\mathrm{C} 20$ & 0.351 & 0.356 & 0.348 & 0.0074 & 0.839 & 0.274 \\
\hline SFA & 72.6 & 72.4 & 71.7 & 0.33 & 0.070 & 0.036 \\
\hline UFA & 27.4 & 27.6 & 28.3 & 0.33 & 0.070 & 0.036 \\
\hline CLA & 0.383 & 0.387 & 0.401 & 0.0114 & 0.293 & 0.212 \\
\hline n-3 & 0.400 & 0.420 & 0.414 & 0.0110 & 0.079 & 0.588 \\
\hline n-6 & 1.72 & 1.74 & 1.77 & 0.014 & 0.006 & 0.056 \\
\hline MUFA & 23.9 & 23.9 & 24.7 & 0.31 & 0.154 & 0.023 \\
\hline PUFA & 2.58 & 2.63 & 2.70 & 0.031 & 0.011 & 0.050 \\
\hline Unknown fatty acids & 0.95 & 1.08 & 0.98 & 0.084 & 0.302 & 0.286 \\
\hline
\end{tabular}

${ }^{1}$ Standard error of the difference.

${ }^{2} \mathrm{HFCG}=$ pooled calcium gluconate effect; Process = mash versus pellet. 
Table 6. Average milk fatty acid yield in response to supplementation with fat-embedded calcium gluconate (HFCG) in a mash or pelleted form $(\mathrm{n}=45)$

\begin{tabular}{|c|c|c|c|c|c|c|}
\hline \multirow{2}{*}{$\begin{array}{l}\text { Fatty acid } \\
\text { yield }(\mathrm{g} / \mathrm{d})\end{array}$} & \multirow[b]{2}{*}{$\mathrm{CON}$} & \multicolumn{2}{|c|}{ Supplement } & \multirow[b]{2}{*}{$\mathrm{SED}^{1}$} & \multicolumn{2}{|c|}{$P$-value ${ }^{2}$} \\
\hline & & Mash & Pellet & & $\mathrm{HFCG}$ & Process \\
\hline $\mathrm{C} 4$ & 45.2 & 47.9 & 46.6 & 1.01 & 0.032 & 0.256 \\
\hline $\mathrm{C} 6$ & 31.2 & 32.1 & 31.3 & 0.50 & 0.266 & 0.169 \\
\hline $\mathrm{C} 8$ & 18.5 & 18.6 & 18.3 & 0.40 & 0.942 & 0.376 \\
\hline $\mathrm{C} 10$ & 49.9 & 49.4 & 49.4 & 1.15 & 0.655 & 0.995 \\
\hline C11 & 0.98 & 0.90 & 0.89 & 0.075 & 0.256 & 0.945 \\
\hline C12 & 55.9 & 55.0 & 54.0 & 1.60 & 0.320 & 0.538 \\
\hline C13 & 1.53 & 1.44 & 1.45 & 0.093 & 0.294 & 0.950 \\
\hline C14 & 177 & 179 & 174 & 3.8 & 0.782 & 0.221 \\
\hline $\mathrm{C} 15$ & 22.9 & 23.1 & 22.6 & 0.44 & 0.928 & 0.349 \\
\hline C16 & 451 & 464 & 449 & 8.3 & 0.403 & 0.103 \\
\hline $\mathrm{C} 17$ & 17.1 & 17.7 & 17.8 & 0.50 & 0.137 & 0.849 \\
\hline C18 & 410 & 425 & 426 & 11.7 & 0.142 & 0.978 \\
\hline $\mathrm{C} 20$ & 4.56 & 4.76 & 4.57 & 0.143 & 0.429 & 0.220 \\
\hline SFA & 946 & 969 & 944 & 16.1 & 0.455 & 0.140 \\
\hline UFA & 357 & 368 & 373 & 8.6 & 0.083 & 0.564 \\
\hline CLA & 4.98 & 5.14 & 5.26 & 0.150 & 0.121 & 0.451 \\
\hline $\mathrm{n}-3$ & 5.21 & 5.60 & 5.47 & 0.193 & 0.062 & 0.493 \\
\hline$n-6$ & 22.3 & 23.2 & 23.3 & 0.52 & 0.056 & 0.881 \\
\hline MUFA & 311 & 318 & 325 & 7.9 & 0.131 & 0.443 \\
\hline PUFA & 33.6 & 35.1 & 35.5 & 0.76 & 0.025 & 0.594 \\
\hline Unknown fatty acids & 12.4 & 14.4 & 12.9 & 1.07 & 0.193 & 0.163 \\
\hline
\end{tabular}

${ }^{1}$ Standard error of the difference.

${ }^{2} \mathrm{HFCG}=$ pooled calcium gluconate effect; Process $=$ mash versus pellet.

$10 \%$

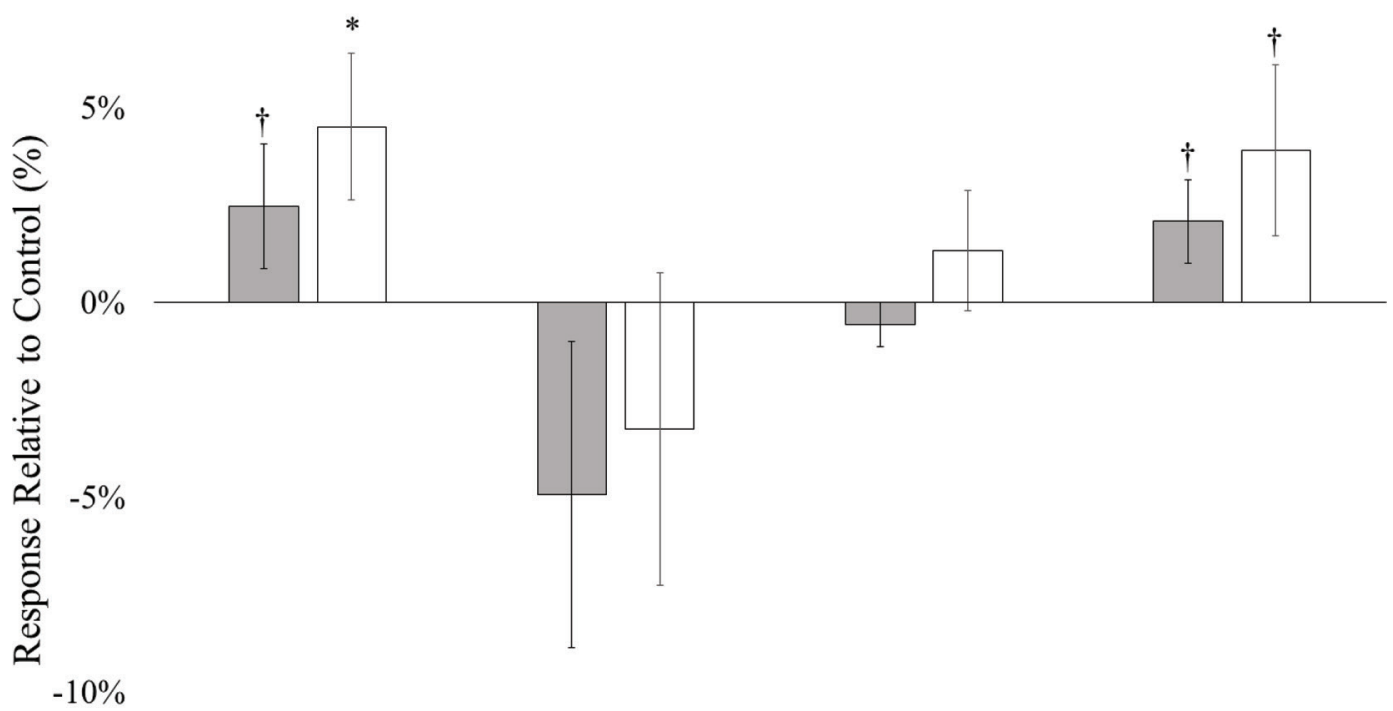

$-15 \%$
C4:0
C4:0 - C:14
$\mathrm{C} 16$
$\mathrm{C} 18+$

Figure 1. Milk butyrate (C4:0), de novo fatty acids (even-chain C4:0-C14), total C16, and preformed fatty acids (C18+) responses to the pooled effect of hydrogenated fat-embedded calcium gluconate supplementation, relative to control. Gray bars represent percent change in milk fatty acid content, whereas white bars represent percent changes in milk fatty acid yield. Significance $(P<0.05)$ is indicated with an asterisk, and tendencies $(0.05 \leq P<0.15)$ with a dagger. Error bars indicate SE of the difference as a percentage of the control mean. 
are formed almost exclusively via de novo synthesis, whereas those $\geq \mathrm{C} 18$ are derived solely from extramammary sources, such as body reserves or diet; C16 fatty acids can be either de novo or extramammary in origin (Grummer, 1991; Garnsworthy et al., 2006). The changes in milk fatty acid content in response to HFCG (Table 5, Figure 1) suggest an overall shift from the de novo synthesis of fatty acids (decreased concentrations of $\mathrm{C} 8$ to $\mathrm{C} 14$ fatty acids) to increased incorporation of preformed fatty acids, which is reflected in the increased yield of fatty acids $\geq 18$ carbons in length. This hypothesis is further supported by the increase in plasma NEFA, which would serve to provide the additional substrates necessary to facilitate the increased incorporation of preformed fatty acids. It is possible that a portion of these preformed fatty acids were derived from dietary sources. As no differences in DMI were observed (Table 4), this would require changes in fat digestibility, and given that HFCG likely acts in the hindgut, changes in fat digestibility are improbable. However, the fat component of the HFCG supplements may have contributed to increased circulating NEFA. The average DMI of animals receiving the HFCG supplements was $23.78 \mathrm{~kg} / \mathrm{d}$, resulting in the consumption of approximately $16.6 \mathrm{~g}$ of HFCG per day, of which 8.3 $\mathrm{g}$ was composed of hydrogenated palm fat. As yields of preformed fatty acids tended to increase by approximately $30.9 \mathrm{~g} / \mathrm{d}(P=0.099)$, this strongly suggests the incorporation of preformed fatty acids of endogenous origin in addition to any contributions derived from the hydrogenated fat component of the supplement. Intriguingly, hindgut acidosis, and presumably hindgut barrier dysfunction, consistently lead to decreases in milk fat content, milk C18, or both (Reynolds et al., 2001; Gressley and Armentano, 2005, 2007) although the underlying mechanisms remain unknown. The fact that HFCG supplementation elicits opposite responses might be indicative of improved hindgut health, consistent with the hypothesized mode of action.

The observed production responses could be explained in part by an increase in production of VFA by hindgut microbes in response to HFCG supplementation, although we observed no difference in fecal acetate, propionate, or butyrate concentrations. This agrees with Doelman et al. (2019a) and is likely due to the rapid uptake of VFA by the gastrointestinal epithelium, limiting the value of fecal VFA content as a marker for hindgut VFA production (den Besten et al., 2013). However, it is possible to estimate the increase in VFA production in response to HFCG supplementation. Tsukahara et al. (2002) observed that gluconate was fermented to butyrate at a molar conversion ratio of $26 \%$ in vitro. Based on a $0.07 \%$ inclusion rate of HFCG in the diet and an average DMI of $23.78 \mathrm{~kg} / \mathrm{d}$, animals in the current study received approximately $16.6 \mathrm{~g}$ of HFCG per day, which provided approximately $6.66 \mathrm{~g}$ of calcium gluconate. This is equivalent to approximately $15.47 \mathrm{mmol}$ of calcium gluconate, which dissociates into $30.95 \mathrm{mmol}$ of gluconate ions. Using the $26 \%$ molar conversion of Tsukahara et al. (2002), it is expected that the amount of HFCG fed would be fermented to approximately $8.05 \mathrm{mmol}(\sim 709 \mathrm{mg})$ of butyrate per day.

Similarly, it is possible to estimate the net change in butyrate incorporated into milk fat. We can assume that butyrate was used as the initial substrate for fatty acid elongation in approximately $50 \%$ of de novo fatty acids, with the other $50 \%$ being derived from acetate (Palmquist et al., 1969). The average yield of fatty acids from 4 to 14 carbons in length numerically decreased by approximately $12.30 \mathrm{~g} / \mathrm{d}(P=0.431$; Figure 1) in animals supplemented with HFCG; assuming an average molecular weight of these fatty acids of 158.241 $\mathrm{g} / \mathrm{mol}$, this translates to an average decrease of 77.73 mmol, sparing approximately $38.86 \mathrm{mmol} \quad(2.424$ $\mathrm{g} / \mathrm{d})$ of butyrate. Additionally, the yield of total C16 increased by approximately $5.99 \mathrm{~g} / \mathrm{d}(P=0.403$; Table 6). Assuming that $50 \%$ of total C16 was derived from de novo synthesis (Palmquist et al., 1969; Grummer, 1991; Garnsworthy et al., 2006) and an average molecular weight of $256.43 \mathrm{~g} / \mathrm{mol}$, this translates to an increase of approximately $11.68 \mathrm{mmol}$ in de novo-derived C16 having been synthesized from approximately $5.84 \mathrm{mmol}$ $(\sim 515 \mathrm{mg})$ of butyrate. Overall, we estimate that the total amount of butyrate incorporated into milk fatty acids decreased by approximately $33.02 \mathrm{mmol}$ (2.909 g) per day. Although not significant, these estimations preclude the direct incorporation of calcium gluconatederived VFA into milk to support the observed milk fat responses to HFCG supplementation.

Increased circulating NEFA in response to HFCG could be mediated through increased lipolysis, decreased re-esterification of fatty acids in adipose tissue, decreased hepatic $\beta$-oxidation, or decreased NEFA uptake and utilization by peripheral tissues (Bell, 1995; Drackley, 2001; Roche et al., 2009). However, the lack of a BW response to HFCG suggests no mobilization of body reserves, and the lack of an insulin response is suggestive of no change in lipolysis. Additionally, the trend for increased BW in the mash versus pelleted treatments suggest a net gain in body reserves in that group. However, these measures do not accurately account for potential changes in fat stores, and as BW was only evaluated during the final week of each period, we cannot comment on any potential changes that occurred while animals adapted to the HFCG supplements. Based on the increase in preformed fatty acids and specifically C18 in milk, we speculate that whole- 
body NEFA utilization was reduced, which is partially supported by the concomitant decrease in blood BHB observed in HFCG-fed cows.

Although no direct measurements of gut health were performed in the current study, we hypothesize that supplementation of the prebiotic HFCG improved yields of milk fat, FCM, and ECM through its action in the hindgut in a way similar to other eubiotic interventions that have shown improved feed efficiency in growing animals (Biagi et al., 2006; Poeikhampha and Bunchasak, 2011; Michiels et al., 2020). The enhanced production of VFA in the hindgut provides a plausible mechanism for both improvements in gut health and modulation of whole-body metabolism (den Besten et al., 2013; Rios-Covian et al., 2016; Liu et al., 2018). The gastrointestinal tract is one of the most energydemanding tissues in the body (McBride and Kelly, 1990). A disruption of intestinal barrier function can further enhance such requirements due to associated immunoactivation (Fox et al., 2005). Improving gut health can potentially alter whole-animal bioenergetics by reducing the energy/nutrient demands of the gastrointestinal tract and sparing resources toward productive purposes, such as milk production. Differences in blood parameters and milk fatty acid profile further support the hypothesis of changes in nutrient partitioning as a mode of action for the observed responses. More work is needed to accurately characterize the response to HFCG at the level of the gastrointestinal epithelium.

It is currently unclear why the yields of bioactive fatty acids (e.g., CLA, n-3, PUFA) increased in response to HFCG supplementation, as these are derived exclusively from the diet and no differences were observed in DMI. Similarly, the response in milk urea requires further investigation. The decrease in fecal isobutyrate in response to HFCG could indicate changes in protein fermentation (Allison, 1978); however, it is unclear how this would elicit a milk urea response of the magnitude observed presently. Characterizing changes in the hindgut microbial community in response to HFCG would help elucidate these findings.

In general, few differences were observed between the mash and pelleted forms of calcium gluconate supplement. Some of the effects observed (e.g., fecal isobutyrate concentration, milk fatty acid content) could reflect the partial fermentation of calcium gluconate in the rumen when fed in the pelleted form. McKnight et al. (2019) incorporated unprotected calcium gluconate into the feed of lactating dairy cattle and observed a numeric decrease in most production parameters. As no performance differences were detected between the 2 processing methods, it is likely that the majority of the calcium gluconate incorporated into the pellets was not fermented in the rumen. More work is needed to evaluate the in situ degradability of the pelleted form.

\section{CONCLUSIONS}

Supplementing animals with a fat-embedded calcium gluconate additive tended to increase milk fat yield, and consequently yields of both FCM and ECM, while also stimulating an increase in milk urea. Milk fatty acid profiles suggest increases in the incorporation of extramammary fatty acids, both of which are supported by the observations in plasma BHB and NEFA. No major differences were observed between the 2 different processing methods used to incorporate the fatembedded calcium gluconate supplement into the diet. More work needs to be done to characterize the effect of HFCG at the level of the gastrointestinal lumen and epithelium, as well as the responses in both milk urea and milk fatty acid profile.

\section{ACKNOWLEDGMENTS}

The authors thank Mieke Langen-Thijssen, Jeroen Doorenbos and the staff at Kempenshof Dairy Research Facility for their contributions to this project. This study was funded by Trouw Nutrition (Amersfoort, the Netherlands), a company that has commercial interest in feed additives. The authors have not stated any other conflicts of interest.

\section{REFERENCES}

Allison, M. J. 1978. Production of branched-chain volatile fatty acids by certain anaerobic bacteria. Appl. Environ. Microbiol. 35:872877. https://doi.org/10.1128/AEM.35.5.872-877.1978.

Asano, T., K. Yuasa, K. Kunugita, T. Teraji, and T. Mitsuoka. 1994. Effects of gluconic acid on human fecal bacteria. Microb. Ecol. Health Dis. 7:247-256. https://doi.org/10.3109https://doi.org// 08910609409141362.

Bell, A. W. 1995. Regulation of organic nutrient metabolism during transition from late pregnancy to early lactation. J. Anim. Sci. 73:2804-2819. https://doi.org/10.2527/1995.7392804x.

Biagi, G., A. Piva, M. Moschini, E. Vezzali, and F. X. Roth. 2006. Effect of gluconic acid on piglet growth performance, intestinal microflora, and intestinal wall morphology. J. Anim. Sci. 84:370-378. https://doi.org/10.2527/2006.842370x.

Cant, J. P., E. J. DePeters, and R. L. Baldwin. 1993. Mammary uptake of energy metabolites in dairy cows fed fat and its relationship to milk protein depression. J. Dairy Sci. 76:2254-2265. https://doi .org/10.3168/jds.S0022-0302(93)77562-1.

den Besten, G., K. van Eunen, A. K. Groen, K. Venema, D. J. Reijngoud, and B. M. Bakker. 2013. The role of short-chain fatty acids in the interplay between diet, gut microbiota, and host energy metabolism. J. Lipid Res. 54:2325-2340. https://doi.org/10.1194/ jlr.R036012.

Doelman, J., L. McKnight, P. Winia, G. Uittenbogaard, M. Carson, D. Waterman, and J. Metcalf. 2019a. The lactational response in dairy cows to supplementation of calcium gluconate embedded in a fat matrix. J. Anim. Sci. 97(Suppl_3):430. https://doi.org/10 $.1093 /$ jas/skz258.852. 
Doelman, J., L. L. McKnight, M. Carson, K. Nichols, D. F. Waterman, and J. A. Metcalf. 2019b. Postruminal infusion of calcium gluconate increases milk fat production and alters fecal volatile fatty acid profile in lactating dairy cows. J. Dairy Sci. 102:1274-1280. https://doi.org/10.3168/jds.2018-15148.

Drackley, J. K. 2001. Management of transition cows: Integrating nutrition and stress physiology. Pages 148-159 in Proc. Cornell Nutr. Conf. Feed Manuf. Cornell University.

Fox, C. J., P. S. Hammerman, and C. B. Thompson. 2005. Fuel feeds function: Energy metabolism and the t-cell response. Nat. Rev. Immunol. 5:844-852. https://doi.org/10.1038/nri1710.

Gaines, W. L. 1928. An efficiency formula for dairy cows. Science 67:353-354. https://doi.org/10.1126/science.67.1735.353.

Gálfi, P., S. Neogrády, and T. Sakata. 1991. Effects of volatile fatty acids on the epithelial cell proliferation of the digestive tract and its hormonal mediation. Pages 49-59 in Physiological Aspects of Digestion and Metabolism in Ruminants, T. Tsuda, Y. Sasaki, and R. Kawashima, ed. Academic Press.

Garnsworthy, P. C., L. L. Masson, A. L. Lock, and T. T. Mottram. 2006. Variation of milk citrate with stage of lactation and de novo fatty acid synthesis in dairy cows. J. Dairy Sci. 89:1604-1612. https://doi.org/10.3168/jds.S0022-0302(06)72227-5.

Gressley, T. F., and L. E. Armentano. 2005. Effect of abomasal pectin infusion on digestion and nitrogen balance in lactating dairy cows. J. Dairy Sci. 88:4028-4044. https://doi.org/10.3168/jds.S0022 $-0302(05) 73089-7$.

Gressley, T. F., and L. E. Armentano. 2007. Effects of low rumendegradable protein or abomasal fructan infusion on diet digestibility and urinary nitrogen excretion in lactating dairy cows. J. Dairy Sci. 90:1340-1353. https://doi.org/10.3168/jds.S0022 -0302(07)71621-1.

Grummer, R. R. 1991. Effect of feed on the composition of milk fat. J. Dairy Sci. 74:3244-3257. https://doi.org/10.3168/jds.S0022 -0302(91)78510-X.

Hamer, H. M., D. Jonkers, K. Venema, S. Vanhoutvin, F. J. Troost, and R. J. Brummer. 2008. Review article: The role of butyrate on colonic function. Aliment. Pharmacol. Ther. 27:104-119. https:// doi.org/10.1111/j.1365-2036.2007.03562.x.

Herrick, K. J., A. R. Hippen, K. F. Kalscheur, D. J. Schingoethe, S. D. Ranathunga, J. L. Anderson, S. C. Moreland, and J. E. van Eys. 2018. Infusion of butyrate affects plasma glucose, butyrate, and beta-hydroxybutyrate but not plasma insulin in lactating dairy cows. J. Dairy Sci. 101:3524-3536. https://doi.org/10.3168/jds .2017-13842.

Huhtanen, P., H. Miettinen, and M. Ylinen. 1993. Effect of increasing ruminal butyrate on milk yield and blood constituents in dairy cows fed a grass silage-based diet. J. Dairy Sci. 76:1114-1124. https://doi.org/10.3168/jds.S0022-0302(93)77440-8.

ISO (International Organization for Standardization). 2013. Milk and liquid milk products - Guidelines for the application of mid-infrared spectrometry. ISO/DIS 9622:2013. ISO, Geneva, Switzerland.

Johnson, M. M., and J. P. Peters. 1993. Technical note: An improved method to quantify nonesterified fatty acids in bovine plasma. J. Anim. Sci. 71:753-756. https://doi.org/10.2527/1993.713753x.

Kristensen, N. B., and D. L. Harmon. 2004. Effect of increasing ruminal butyrate absorption on splanchnic metabolism of volatile fatty acids absorbed from the washed reticulorumen of steers. J. Anim. Sci. 82:3549-3559. https://doi.org/10.2527/2004.82123549x.

Kvidera, S. K., E. A. Horst, M. Abuajamieh, E. J. Mayorga, M. V. S. Fernandez, and L. H. Baumgard. 2017. Glucose requirements of an activated immune system in lactating holstein cows. J. Dairy Sci. 100:2360-2374. https://doi.org/10.3168/jds.2016-12001.

Leonel, A. J., L. G. Teixeira, R. P. Oliveira, A. F. Santiago, N. V. Batista, T. R. Ferreira, R. C. Santos, V. N. Cardoso, D. C. Cara, A. M. Faria, and J. Alvarez-Leite. 2013. Antioxidative and immunomodulatory effects of tributyrin supplementation on experimental colitis. Br. J. Nutr. 109:1396-1407. https://doi.org/10.1017/ S000711451200342X

Liu, H., J. Wang, T. He, S. Becker, G. Zhang, D. Li, and X. Ma. 2018. Butyrate: A double-edged sword for health? Adv. Nutr. 9:21-29. https://doi.org/10.1093/advances/nmx009.
McBride, B. W., and J. M. Kelly. 1990. Energy cost of absorption and metabolism in the ruminant gastrointestinal tract and liver: A review. J. Anim. Sci. 68:2997-3010. https://doi.org/10.2527/1990 .6892997x.

McKnight, L. L., J. Doelman, M. Carson, D. F. Waterman, and J. A. Metcalf. 2019. Feeding and postruminal infusion of calcium gluconate to lactating dairy cows. Can. J. Anim. Sci. 99:563-569. https: //doi.org/10.1139/cjas-2018-0154.

Mentschel, J., R. Leiser, C. Mulling, C. Pfarrer, and R. Claus. 2001. Butyric acid stimulates rumen mucosa development in the calf mainly by a reduction of apoptosis. Arch. Tierernahr. 55:85-102. https://doi.org/10.1080/17450390109386185.

Michiels, J., D. Truffin, M. Majdeddin, E. Van Liefferinge, N. Van Noten, M. Vandaele, C. Van Kershchaver, J. Degroote, and P. Linder. 2020. L'acide gluconique améliore les performances des porcelets nouvellement sevrés associées avec des modifcations au niveau du microbiote intestinal et de la fermentation. Pages 177-178 in Proc. 52ennes Journées de la Recherche Porcine, Paris.

Miettinen, H., and P. Huhtanen. 1996. Effects of the ratio of ruminal propionate to butyrate on milk yield and blood metabolites in dairy cows. J. Dairy Sci. 79:851-861. https://doi.org/10.3168/jds .S0022-0302(96)76434-2.

Miyoshi, M., H. Sakaki, M. Usami, N. Iizuka, K. Shuno, M. Aoyama, and Y. Usami. 2011. Oral administration of tributyrin increases concentration of butyrate in the portal vein and prevents lipopolysaccharide-induced liver injury in rats. Clin. Nutr. 30:252-258. https://doi.org/10.1016/j.clnu.2010.09.012.

Nichols, K., J. J. M. Kim, M. Carson, J. A. Metcalf, J. P. Cant, and J. Doelman. 2016. Glucose supplementation stimulates peripheral branched-chain amino acid catabolism in lactating dairy cows during essential amino acid infusions. J. Dairy Sci. 99:1145-1160. https://doi.org/10.3168/jds.2015-9912.

Palmquist, D. L., C. L. Davis, R. E. Brown, and D. S. Sachan. 1969. Availability and metabolism of various substrates in ruminants. V. Entry rate into the body and incorporation into milk fat of $\mathrm{d}(-)$ ß-hydroxybutyrate. J. Dairy Sci. 52:633-638. https://doi.org/10 .3168/jds.S0022-0302(69)86620-8.

Papas, A., and S. H. Wu. 1997. Rumen-stable delivery systems. Adv. Drug Deliv. Rev. 28:323-334. https://doi.org/10.1016/S0169 $-409 \mathrm{X}(97) 00087-2$.

Poeikhampha, T., and C. Bunchasak. 2011. Comparative effects of sodium gluconate, mannan oligosaccharide and potassium diformate on growth performances and small intestinal morphology of nursery pigs. Asian-Australas. J. Anim. Sci. 24:844-850. https:// doi.org/10.5713/ajas.2011.10334.

Raabo, E., and T. C. Terkildsen. 1960. On the enzymatic determination of blood glucose. Scand. J. Clin. Lab. Invest. 12:402-407. https://doi.org/10.3109/00365516009065404.

Ramachandran, S., P. Fontanille, A. Pandey, and C. Larroche. 2006. Gluconic acid: Properties, applications and microbial production. Food Technol. Biotechnol. 44:185-195.

Reynolds, C. K., S. B. Cammell, D. J. Humphries, D. E. Beever, J. D. Sutton, and J. R. Newbold. 2001. Effects of postrumen starch infusion on milk production and energy metabolism in dairy cows. J. Dairy Sci. 84:2250-2259. https://doi.org/10.3168/jds.S0022 $-0302(01) 74672-3$

Ríos-Covián, D., P. Ruas-Madiedo, A. Margolles, M. Gueimonde, C. G. de los Reyes-Gavilán, and N. Salazar. 2016. Intestinal short chain fatty acids and their link with diet and human health. Front. Microbiol. 7:185. https://doi.org/10.3389/fmicb.2016.00185.

Roche, J. R., N. C. Friggens, J. K. Kay, M. W. Fisher, K. J. Stafford, and D. P. Berry. 2009. Invited review: Body condition score and its association with dairy cow productivity, health, and welfare. J. Dairy Sci. 92:5769-5801. https://doi.org/10.3168/jds.2009-2431.

Sakata, T., and H. Tamate. 1978. Rumen epithelial-cell proliferation accelerated by rapid increase in intra-ruminal butyrate. J. Dairy Sci. 61:1109-1113. https://doi.org/10.3168/jds.S0022 -0302(78)83694-7.

Sanz-Fernandez, M. V., J.-B. Daniel, D. J. Seymour, S. K. Kvidera, Z. Bester, J. Doelman, and J. Martín-Tereso. 2020. Targeting the 
hindgut to improve health and performance in cattle. Animals (Basel) 10:1817-1835. https://doi.org/10.3390/ani10101817.

Seymour, D. J., A. Cánovas, C. F. Baes, T. C. S. Chud, V. R. Osborne, J. P. Cant, L. F. Brito, B. Gredler-Grandl, R. Finocchiaro, R. F. Veerkamp, Y. de Haas, and F. Miglior. 2019. Invited review: Determination of large-scale individual dry matter intake phenotypes in dairy cattle. J. Dairy Sci. 102:7655-7663. https://doi.org/ $10.3168 /$ jds.2019-16454.

Sjaunja, L. O., L. Baevre, L. Junkkarinen, J. Pedersen, and J. Setala. 1990. A Nordic proposal for an energy corrected milk (ECM) formula. In Proc. Int. Comm. for Breeding and Productivity of Milk Animals. ICAR.

Tsukahara, T., K. Hashizume, H. Koyama, and K. Ushida. 2006. Stimulation of butyrate production through the metabolic interaction among lactic acid bacteria, Lactobacillus acidophilus, and lactic acid-utilizing bacteria, Megasphaera elsdenii, in porcine cecal digesta. Anim. Sci. J. 77:454-461. https://doi.org/10.1111/j.1740 -0929.2006.00372.x.

Tsukahara, T., H. Koyama, M. Okada, and K. Ushida. 2002. Stimulation of butyrate production by gluconic acid in batch culture of pig cecal digesta and identification of butyrate-producing bacteria. J. Nutr. 132:2229-2234. https://doi.org/10.1093/jn/132.8.2229.

Velázquez, O. C., H. M. Lederer, and J. L. Rombeau. 1997. Butyrate and the colonocyte. Production, absorption, metabolism, and therapeutic implications. Adv. Exp. Med. Biol. 427:123-134.

Wächtershäuser, A., and J. Stein. 2000. Rationale for the luminal provision of butyrate in intestinal diseases. Eur. J. Nutr. 39:164-171. https://doi.org/10.1007/s003940070020.
Weber, W. J., C. R. Wallace, L. B. Hansen, H. Chester-Jones, and B. A. Crooker. 2007. Effects of genetic selection for milk yield on somatotropin, insulin-like growth factor-i, and placental lactogen in holstein cows. J. Dairy Sci. 90:3314-3325. https://doi.org/10 $.3168 /$ jds.2006-899.

Weekes, T. L., P. H. Luimes, and J. P. Cant. 2006. Responses to amino acid imbalances and deficiencies in lactating dairy cows. J. Dairy Sci. 89:2177-2187. https://doi.org/10.3168/jds.S0022 -0302(06)72288-3.

Wu, Z., J. K. Bernard, R. B. Eggleston, and T. C. Jenkins. 2012. Ruminal escape and intestinal digestibility of ruminally protected lysine supplements differing in oleic acid and lysine concentrations. J. Dairy Sci. 95:2680-2684. https://doi.org/10.3168/jds.2011-5203.

\section{ORCIDS}

D. J. Seymour @ https://orcid.org/0000-0001-6208-8720

M. V. Sanz-Fernandez @ https://orcid.org/0000-0002-0678-1149

J. B. Daniel ๑ https://orcid.org/0000-0001-7627-3708

J. Martín-Tereso 으 https://orcid.org/0000-0002-6757-4629

J. Doelman @ https://orcid.org/0000-0002-3328-8042 